\title{
SOROTAN YOHANES 17:20-23 \\ TENTANG KESATUAN ALLAH DAN MANUSIA TERHADAP MISTIK TOENGGOEL WOELOENG
}

\author{
Fredi Purwanto
}

\section{PENDAHULUAN}

Salah satu tokoh dalam sejarah penginjilan abad XIX di Jawa Tengah yang bernama Toenggoel Woeloeng telah mencoba mengawali hibridisasi (pengawinan) teologi Barat dengan konteks mistik lokal yang melahirkan mistik Kristen Kejawen. Mengenai tokoh ini van den End menjelaskan bahwa:

Ia berasal dari daerah Juwono (juga dekat Gunung Muria). Pada tahun-tahun itu penduduk Jawa Tengah menjadi resah akibat keadaan ekonomi mereka yang sulit. Banyak orang yang mengungsi ke Jawa Timur. Kyai Ngabdullah, begitulah namanya waktu itu, ikut berpindah dan menjadi seorang pertapa di lereng Gunung Kelud. Rupanya ia dipandang orang sebagai penjelmaan seorang tokoh dari zaman raja Joyoboyo, yaitu seorang jenderal yang bernama Tunggul Wulung. ${ }^{1}$

Kiai Toenggoel Woeloeng merupakan seorang pemimpin Jemaat Kristen Jawa di desa Bondo yang sangat dihormati para pengikutnya. Untuk menunjukkan kemuliaannya, dia memakai tanda kebesaran, yaitu yang disebut "Payung Agung" serta memakai gelar yang menunjukkan kehormatan dirinya, yaitu Kanjeng Rama Ana. Gagasan mistik Toenggoel Woeloeng tersebut (Kanjeng Rama Ana = Bapa yang Mewujud dan Kristus yang kelihatan) berakar pada ajaran mistik Jawa, Manunggaling KawulaGusti, serta pengaruh dari konsep Mahdisme dan Mesianisme. Pendapat ini didasarkan pada kenyataan, bahwa sebelum menjadi Kristen Toenggoel Woeloeng adalah seorang guru ngelmu yang mengajarkan ngelmu tersebut.

Kekristenan yang diajarkan Toenggoel Woeloeng di Bondo menurutnya adalah ngelmu. Doa Bapa Kami, Dasa Titah, dan 12 Sahadat

\footnotetext{
${ }^{1}$ Th. van den End, Ragi Carita 1: Sejarah Gereja di Indonesia th. 1500 - th. 1860 (Jakarta: BPK Gunung Mulia, 1980), 206
} 
adalah ngelmu, yang bila dihafal dan disyarati dengan laku-laku, akan menghasilkan daya magis tersendiri. Karena pemahaman Toenggoel Woeloeng terhadap Injil adalah ngelmu, maka pewartaan Injil yang dilakukan terhadap orang-orang tertentu kadang dalam bentuk "adu ngelmu", baik dari segi kesaktian maupun debat. Otoritas Toenggoel Woeloeng adalah kharisma, yakni kesaktiannya (kasekten) yang diperolehnya kala ia menjadi seorang pertapa. Ia juga melakukan kunjungan manakala ada orang sakit, lalu ia akan menyembuhkannya dengan jalan menggosok, meludah, atau meniup pada bagian tubuh yang sakit, atau juga ia akan berkomat-kamit. ${ }^{2}$

Dengan mencermati hal-hal tersebut, maka kajian terhadap tokoh Toenggoel Woeloeng ini pada satu sisi akan menunjukkan adanya fenomena kritis pada bahaya tradisi budaya spiritual lokal bila menjadi dominan, sehingga penulis terdorong untuk mengkaji lebih jauh hal tersebut dalam satu kajian.

\section{BAB I}

\section{LATAR BELAKANG KEHIDUPAN KIAI TOENGOEL WOELOENG}

Dalam pemaparan latar belakang kehidupan Kiai Toenggoel Woeloeng ini, penulis akan menguraikan mengenai Asal-usul dan Pemikiran-pemikiran Kiai Toenggoel Woeloeng.

\section{Asal-usul Kiai Toenggoel Woeloeng}

Salah seorang tokoh pemimpin dalam kekristenan Jawa ialah Toenggoel Woeloeng, yaitu sekitar tahun 1803-1885. Ia berasal dari distrik Juwono di Jepara (juga dekat Gunung Muria), di pantai utara Jawa Tengah dan termasuk kalangan priyayi. Sebelum ia menjadi pertapa, kemungkinan ia memiliki hubungan dengan bangsawan kraton di daerah istimewa Jawa Tengah. Cerita turun-temurun mengenai hal itu tidak begitu jelas. ${ }^{3}$ Demikian juga Guillot menyatakan bahwa masa mudanya tidak begitu banyak diketahui, dan dia adalah seorang petani seperti terdapat dalam

\footnotetext{
${ }^{2}$ Philip van Akkeren, Dewi Sri dan Kristus: Sebuah Kajian Tentang Gereja Pribumi di Jawa Timur. B.A. Abednego, terj., (Jakarta: BPK Gunung Mulia, 1995), 210

${ }^{3}$ A.G. Hoekema, Berpikir dalam Keseimbangan yang Dinamis: Sejarah Lahirnya Teologi Protestan Nasional di Indonesia (Sekitar 1860 - 1960), Amsy Susilaradeya, terj., (Jakarta: BPK Gunung Mulia, 1997), 62; Golongan priyayi adalah kaum bangsawan Jawa yang direkrut menjadi pegawai negeri pribumi.
} 
laporan-laporan residen Jepara. ${ }^{4}$ Yang jelas, pada tahun-tahun itu penduduk Jawa Tengah menjadi resah akibat keadaan ekonomi mereka yang sulit. Banyak orang yang mengungsi ke Jawa Timur. Kyai Ngabdullah, begitulah namanya pada waktu itu, ikut berpindah dan menjadi seorang pertapa di lereng Gunung Kelud. ${ }^{5}$ Rupanya ia dipandang orang sebagai penjelmaan seorang tokoh dari zaman raja Jayabaya, yaitu seorang Jenderal yang bernama Toenggoel Woeloeng.

Pada masa ini Toenggoel Woeloeng berkenalan dengan agama Kristen. Caranya tidak kita ketahui dengan tepat, tetapi baik Ngoro maupun Mojowarno letaknya tidak jauh dari Gunung Kelud, sedangkan pada tahun 1840-an agama Kristen sudah cukup terkenal di kalangan penganut Kebatinan. ${ }^{6}$ Berkaitan dengan masuknya Toenggoel Woeloeng ke dalam agama Kristen, ada beberapa versi.

Yang pertama versi Toenggoel Woeloeng sendiri, menurut Muller bahwa ceritanya kepada Jellesma mengenai alasannya hendak masuk Kristen adalah aneh. Dengan tak disangka-sangka, demikian ceritanya, ia menemukan di bawah tikar tempatnya bertapa kesepuluh perintah Allah serta ia mendapat ilham untuk pergi ke Mojowarno. ${ }^{7}$ Hal senada juga diungkapkan oleh Lydia dalam bukunya, yaitu bahwa:

Berdasarkan catatan dari penginjil Harthoorn yang ditulis pada tahun 1855, Kiai Tunggul Wulung pernah mengatakan bahwa pada suatu hari ketika masih bertapa di Gunung Kelud ia menemukan salinan Sepuluh Perintah Allah di bawah tikarnya. Menurut pendapatnya, salinan tersebut diletakkan oleh tangan Tuhan sendiri, dengan disertai suara dari langit yang memerintahkannya agar pergi ke hutan di daerah Mojopahit, untuk menemui seorang Pendeta Belanda yang akan menunjukkan jalan keselamatan baginya. Berdasarkan pada perintah itu, ia bersama kakaknya yang bernama Jayatruna pergi ke Mojowarno untuk belajar agama Kristen pada penginjil J.E. Jellesma. ${ }^{8}$

Mengenai hal tersebut, Guillot mengutip komentar Jellesma yang menyatakan bahwa, "Dia (Toenggoel Woeloeng) telah mendengar orang berbicara tentang diri saya dan Injil di sana-sini, dan hal ini terpikir dalam

\footnotetext{
${ }^{4}$ C. Guillot, Kiai Sadrach: Riwayat Kristenisasi di Jawa, Asvi Warman Adam, terj., (Jakarta: PT Grafiti Pers, 1985), 42

${ }^{5}$ Th. van den End, Ragi Carita 1: Sejarah ....., 206

${ }^{6}$ Ibid.

7 Th. Muller Kruger, Sedjarah Geredja di Indonesia, Tjetakan kedua, (Djakarta: Badan Penerbit Kristen, 1966), 189

${ }^{8}$ Lydia Herwanto, Pikiran dan Aksi Kiai Sadrach: Gerakan Jemaat Kristen Jawa Merdeka, (Jogjakarta: MATABANGSA, 2002), 47
} 
semadinya dan kemudian dia mengira mendengar sebuah suara yang menyuruhnya datang menemui saya". 9 Tidak dapat diketahui dengan pasti berapa lama ia tinggal di Mojowarno, yang diketahui hanya sebelum ia kembali ke Gunung Kelud, penginjil J.E. Jellesma memberinya beberapa buah Alkitab berbahasa Jawa untuk dipelajarinya lebih lanjut. Menanggapi masalah itu, Lidya mengutip pernyataan Adriaanse yang memberikan tanggapan sebagai berikut: "Kepada saya dia (Kiai Toenggoel Woeloeng) mengatakan bahwa ia sangat berbahagia karena membaca Sepuluh Perintah Allah, tetapi menurut penginjil J.E. Jellesma, Kiai itu baru belajar membaca ketika tinggal bersamanya. Untuk menutupi kelemahan ini, dia mengatakan bahwa Tuhan sendiri yang memerintahkannya untuk belajar pada penginjil J.E. Jellesma. ${ }^{10}$

Versi kedua menurut Janz, Toenggoel Woeloeng menuturkan kepadanya bahwa ia menjadi Kristen lewat perantaraan seorang pandito dari Gunung Tayu yang telah pergi ke Surabaya. Jellesma dan Adriaanse membenarkan bahwa keduanya telah mengunjungi kelompok Emde dan juga menemui Coolen. Guillot berpendapat bahwa keragaman versi ini memperlihatkan konsekuensi dari munculnya berbagai jemaah Kristen di Pulau Jawa. ${ }^{11}$ Terlepas dari bagaimana asal muasalnya masuk Kristen, yang jelas pada tahun 1853 Toenggoel Woeloeng muncul di Mojowarno, dan dua tahun kemudian ia dibaptis oleh Jellesma dan diberi nama Ibrahim. ${ }^{12}$ Sementara itu dan juga sesudahnya ia mengadakan perjalanan PI terusmenerus, antara lain ke Pasuruan, Rembang, di daerah Malang dan di kawasan Gunung Muria, kemudian juga di Jawa Barat. Di beberapa tempat ia menjadi perintis jemaat-jemaat Kristen yang baru. Berkaitan dengan hal itu, Muller menyatakan bahwa:

Tiada putus $^{2}$ nya Toenggoel Woeloeng mengembara sebagai pengindjil dengan ichtiar sendiri. Dari desa ke desa, dari kota ke kota di Djawa Timur, Djawa Utara malahan sampai ke Djawa Barat. Ia mentjari hubungan dengan Mr. Anthing dan anaknja pun menjadi seorang pengindjil di dalam djemaat ${ }^{2}$ Anthing. Sadrach pun menjadi penganutnja pada waktu ia mengumpulkan sejumlah keluarga Djawa dari Semarang dan sekitarnja, dengan maksud untuk mendirikan satu desa Kristen di Bondo dan di Banju Towo. $^{13}$

\footnotetext{
${ }^{9}$ C. Guillot, Kiai Sadrach: Riwayat Kristenisasi di Jawa ....., 43

${ }^{10}$ Lydia Herwanto, Pikiran dan Aksi Kiai Sadrach....., 47

${ }^{11}$ C. Guillot, Kiai Sadrach: Riwayat Kristenisasi di Jawa....., 43

${ }^{12}$ Th. van den End, Ragi Carita 1....., 206

${ }^{13}$ Th. Muller Kruger, Sedjarah Geredja di Indonesia....., 189
} 
Kegiatan ini sempat menimbulkan rasa gelisah di kalangan pemerintah Hindia-Belanda begitu rupa, sehingga sampai-sampai Gubernur-Jenderal dan Menteri daerah-daerah Jajahan mengutarakan pendapat mereka. Pun zendeling Janz, utusan pertama dari lembaga Zending Mennonit, yang sejak tahun 1852 menetap di daerah Jepara, mengecam cara-cara yang ditempuh oleh Kiai Jawa ini. Bahkan terjadi konflik di antara Janz dan Toenggoel Woeloeng pada tahun 1854. Hal ini terjadi karena Janz menolak permintaan Toenggoel Woeloeng yang datang kepadanya untuk minta dibaptis. Alasan Janz adalah bahwa iman Toenggoel Woeloeng terlalu diwarnai unsur-unsur kejawen sehingga permintaan itu ditolaknya. ${ }^{14}$ Tetapi Toenggoel Woeloeng tidak membiarkan kegiatannya ditahan; selama duapuluh tahun ia berkeliling terus. Pada waktu kematiannya, 29 April 1885, jumlah pengikutnya adalah 1.058 di tiga desanya. ${ }^{15}$

\section{Pemikiran-pemikiran Kiai Toenggoel Woeloeng}

Ada beberapa pemikiran Kiai Ibrahim Toenggoel Woeloeng yang akan penulis uraikan pada bagian ini, yaitu Serat Darmogandul yang merupakan hasil pergulatan batin di pertapaan Gunung Kelud, Identitas Jemaat Kristen Jawa, Injil Sebagai Ngelmu Kristen dan Kristologi Ratu Adil.

\section{Serat Darmogandul}

Pada bagian sebelumnya telah disebutkan bahwa Toenggoel Woeloeng bertapa di Gunung Kelud. Dalam pertapaannya di Gunung Kelud itulah Ngabdullah mengambil nama Toenggoel Woeloeng. Secara harafiah, Toenggoel berarti "yang lurus" atau "di depan" dan Woeloeng "warna dasar ungu". Juga nama ini dipakai sebagai salah satu panji dalam kisah Panji. Sebuah panji memakai nama ini terdapat di antara pusaka Keraton Yogyakarta. Toenggoel Woeloeng juga merupakan nama seorang panglima legendaris raja kuno Jayabaya dari Kediri. Roh sang panglima katanya tinggal di kawah Gunung Kelud, di sanalah ia dan (atau) Lingga Siwa menjaga api kawah. ${ }^{16}$

Berhubung sang pertapa mengenakan nama penting Toenggoel Woeloeng, dapatlah kiranya kita menduga bahwa ia, misalnya seperti

\footnotetext{
14 Th. van den End, Ragi Carita 2: Sejarah Gereja Di Indonesia 1860-an - sekarang, (Jakarta: BPK Gunung Mulia, 2000), 232

${ }^{15}$ Philip van Akkeren, Dewi Sri Dan Kristus: Sebuah Kajian ....., 210

${ }^{16}$ C. Guillot, Kiai Sadrach: Riwayat Kristenisasi di Jawa ....., 42
} 
panglima Jayabaya dan Diponegoro, berikhtiar memperoleh kekuatan supranatural atas dunia, manusia dan alam roh, dengan jalan meditasi, perenungan, penjernihan batin serta pemusatan diri: kuasa atas kedalaman terdalam (mikrokosmos), juga menghasilkan kuasa atas makrokosmos. ${ }^{17}$ Selain itu, Lydia menyatakan bahwa dengan bertapa ia berharap dapat memahami makna kehidupan dan memperoleh kebenaran sejati serta menyatukan diri dengan Tuhan. Hal ini menunjukkan sifat mistik dari Kiai Toenggoel Woeloeng. ${ }^{18}$

Menurut Zoetmulder, tindakan bertapa pada zaman kuno tidak hanya dimaksudkan untuk mendapat kesaktian. Para seniman dan ahli sastra (juru kawi) melakukan tapa-brata, bukan demi memperoleh daya sakti, tetapi daya estetika yang tinggi. Jadi dalam hal ini, dewa keindahan bisa dimohon paksa untuk menampilkan diri dalam kesatuan yang terjadi di lubuk dasar pengalaman estetis sang pertapa. Karena itu, seorang juru-kawi dalam menciptakan puisi (kalangwan, kalangön) ia akan bertapa untuk dapat mempersepsi dewa dalam suatu irama keindahan yang hendak ia capai; karena dewa itu hadir dalam manifestasi keindahan. ${ }^{19}$ Karena bertapa itu tidak selalu memohon kadigdayan atau kesaktian, tetapi juga untuk eksis dalam manifestasi estetika, maka ada kemungkinan bahwa Toenggoel Woeloeng dalam masa bertapanya menghasilkan karya keindahan, baik syair hikmat atau rumusan-rumusan mantra, yakni Serat Darmogandul.

Dalam buku Jawa Serat Darmogandul, Toenggoel Woeloeng digambarkan sebagai Jendral di zaman Raja Jayabaya di Kediri. Sesudah raja mangkat, Toenggoel Woeloeng bersama abangnya, Kiai Daha, alias Buta Locaya, yang menjabat Perdana Menteri dalam pemerintahan Jayabaya, konon harus melindungi kerajaan Kediri. Buta Locaya ditugaskan menjadi roh yang menjaga Kediri dari atas Gunung Wilis, sedangkan Toenggoel Woeloeng diberi tugas yang sama tetapi dari atas sebuah gunung berapi, Gunung Kelud. Dalam Serat Darmogandul muncul "ramalan" yang sangat menarik bahwa Islam hanya 500 tahun lamanya berkuasa di bumi. Sesudah itu agama buda (aliran Hindu) bersama agama kawruh (zaman modern atau agama Kristen) mengambil alih kekuasaan lagi. Dalam memaksakan pembatasan terhadap periode dan kekuasaan Islam, juga dalam perubahan drastis yang akan terjadi di abad ke-19, Buta Locaya memainkan peran menurut Serat Darmogandul. Meskipun namanya tidak disebut secara menonjol, sebagai adik Buta Locaya, Toenggoel Woeloeng pun terlibat dalam peran itu. ${ }^{20}$

\footnotetext{
${ }^{17}$ Philip van Akkeren, Dewi Sri Dan Kristus...., 208

${ }^{18}$ Lydia Herwanto, Pikiran Dan Aksi Kiai Sadrach...., 46

${ }^{19}$ P.J. Zoetmulder, Kalangwan, (Jakarta: Jambatan, 1994), 207

${ }^{20}$ A.G. Hoekema, Berpikir dalam Keseimbangan yang Dinamis....., 63
} 
Van Akkeren membela hipotesis bahwa Kiai Toenggoel Woeloeng adalah penyusun Serat Darmogandul. Ia menjelaskan mengapa dalam naskah Serat Darmogandul sendiri penyebutan nama itu dihindari; penulis, atau sekurang-kurangnya redaktur, tidak mau menyebut nama itu karena ia rendah hati atau karena alasan lainnya. Sebuah masalah dalam hipotesis Van Akkeren ini ialah penanggalan dalam naskah itu dan kaitannya dengan penulisan yang berhubungan dengannya, yakni Babad Kediri. Berkaitan dengan hal tersebut Van Akkeren menyatakan bahwa Babad Kediri adalah saduran pendek yang dibuat di kemudian hari dari gagasan utama Serat Darmogandul. Naskah tersebut selesai tidak lama sesudah perang Diponegoro (1825-1830). Diperkirakan bahwa Kiai Toenggoel Woeloeng mempublikasikannya sebelum ia pindah ke agama Kristen. ${ }^{21}$

\section{Identitas Jemaat Kristen Jawa}

Jemaat yang didirikan oleh orang-orang awam dan penginjil Jawa bersifat integratif. Walaupun mereka yang bertobat dibaptis oleh Pendeta dari kelompok lain, mereka membentuk jemaat Jawa yang terpisah. Karena mereka mendorong orang Jawa tetap menjadi bagian dari budaya dan masyarakat mereka, maka jemaat ini dapat tumbuh secara pesat. $^{22}$ Demikian juga dengan jemaat yang didirikan oleh Toenggoel Woeloeng. Pengikut Toenggoel Woeloeng lebih merasa dirinya sebagai Kristen Jawa dibandingkan dengan orang-orang Kristen yang dipimpin misionaris yang disebut Kristen Londo. Toenggoel Woeloeng sendiri berpendapat: "Tidaklah baik bagi orang-orang Jawa berkumpul di kediaman misionaris Belanda". ${ }^{23}$ Sebenarnya Toenggoel Woeloeng sendiri senang berkenalan dengan orang-orang Kristen Belanda, serta mengunjungi mereka dari waktu ke waktu, tetapi ia tidak menyetujui sistem pewalian zending. ${ }^{24}$ Hal tersebut akan mengurangi kebebasannya dalam menentukan kebijakan bagi jemaat yang dipimpinnya, sedangkan ia adalah tipe seorang yang mempunyai pendirian bebas. ${ }^{25}$ Hal itu dibuktikan dengan sikap Kiai Toenggoel Woeloeng yang menolak kerja sama dengan penginjil Peter Janz, utusan Doopsgezinde Zending Vereeniging (DZV) yang bertugas di daerah Jepara.

${ }^{21}$ Philip van Akkeren, "Darmogandul Suluk Karangan Ngabdullah Tunggul Wulung Hubungannya dengan Pekabaran Injil di Jawa Timur", Dalam Mengenang 50 tahun Majelis Agung Gereja Kristen Jawi Wetan, Suharo dan Sardjonan, red. Pp. 138-144., (Malang: Majelis Agung GKJW, 1981), 138-139

${ }^{22}$ Soetarman Soediman Patronadi, Komunitas Sadarch dan Akar Kontekstualnya: Suatu Ekspresi Kekristenan Jawa pada Abad XIX, Widi Herijati Rahadi, terj., (Jakarta: BPK Gunung Mulia, 2001), 52

${ }^{23}$ C. Guillot, Kiai Sadrach: Riwayat Kristenisasi di Jawa ....., 46

${ }^{24}$ Philip van Akkeren, Dewi Sri dan Kristus....., 210

${ }^{25}$ Lydia Herwanto, Pikiran Dan Aksi Kiai Sadrach....., 49 
Toenggoel Woeloeng sendiri menjadi pemimpin jemaat itu. Dengan pernyataannya bahwa Tuhan sendiri yang memerintahkannya untuk belajar pada penginjil J.E. Jellesma. Toenggoel Woeloeng ingin menunjukkan kepada masyarakat sekitarnya bahwa ia memang ditakdirkan untuk menjadi pemimpin, dan kepemimpinannya sudah disahkan oleh kekuatan supranatural. ${ }^{26}$ Jadi, pernyataannya yang menyatakan bahwa ia mendapat perintah Tuhan, merupakan suatu tindakan untuk mendapatkan pengakuan dalam kedudukannya sebagai pemimpin Jemaat Kristen Jawa. Selain itu, untuk menunjukkan kemuliaannya dia memakai tanda kebesaran, yaitu yang disebut "Payung Agung" serta memakai gelar yang menunjukkan kehormatan dirinya, yaitu "Kanjeng Rama Ana" ${ }^{27}$ Di desa Bondo, di mana ia tinggal, Toenggoel Woeloeng dikenal dengan sebutan "Kiai Kristen" dan "Dukun Kristen".

Keunikan-keunikan dalam Jemaat Kristen Jawa adalah bahwa Toenggoel Woeloeng tidak menganggap gereja sebagai persekutuan orangorang suci seperti dipahami oleh para penginjil, tetapi ia sangat rajin untuk mengumpulkan "umat Allah" di sekelilingnya yang ditafsirkan sebagai "seluruh umat manusia". ${ }^{28} \mathrm{Jadi}$, secara tidak langsung ia menyebut semua orang dengan sebutan "umat Allah". Bangunan gereja disebutnya dengan "masjid". 29

Keunikan lain dari jemaat Kristen Bondo adalah bahwa mereka melakukan dzikir. ${ }^{30}$ Pada malam-malam tertentu diadakan doa bersama, yang pengaturannya mirip dengan dzikir yang dilakukan kelompok Islam. Hanya dalam dzikir ini rumusan kredonya diubah Toenggoel Woeloeng menjadi, "La ilaha illa 'l-Allah, Yesus Kristus Putraning Allah. La ilaha illa 'l-Allah, Yesus Kristus Rohollah". ${ }^{11}$ Bila diperhatikan rumusan tersebut kesannya Toenggoel Woeloeng memasukkan unsur Islam ke dalam Kristen, yaitu memadukan "sahadat Islam" dengan Kristen. Namun kalau kita memperhatikan pendapat Warsito, bahwa sahadat yang tidak menggunakan "Mohammad Rosullah" itu justru berasal dari "kawruh kejawen"; bukan dari Qur'an atau sunah Nabi Mohammad. ${ }^{32}$ Itu berarti rumusan tersebut adalah perpaduan kejawen dengan Kristen. Tetapi harus diakui bahwa "kawruh kejawen" itu pun juga telah mengalami sinkretisasi dengan Islam. Hal itu terbukti dari penggunaan terminologi Arab "La ilaha illa 'l-Allah" tersebut.

\footnotetext{
${ }^{26}$ Ibid., 48

${ }^{27}$ L. Adriaanse, Sadrach's King, (Leiden: Donner, 1899), 42-43

${ }^{28}$ A.G. Hoekema, Berpikir dalam Keseimbangan yang Dinamis....., 69

${ }^{29}$ L. Adriaanse, Sadrach's King, (Leiden: Donner, 1899), 50

${ }^{30}$ Th. van den End, Ragi Carita 1....., 207

31 J.D. Walterbeek, Babad Zending di Pulau Jawa, (Yogyakarta: Taman Pustaka Kristen, 1995), 15

${ }^{32}$ Warsito, di Sekitar Kebatinan, (Jakarta: Bulan Bintang, 1973), 50
} 
Menurut Koentjaraningrat, dzikir semacam ini biasa dilakukan oleh para santri pada suatu kesempatan khusus, juga oleh kaum abangan dalam acara slametan untuk orang meninggal. ${ }^{33}$ Selain itu, Poensen juga mencatat bahwa dzikir merupakan salah satu tradisi yang dilestarikan dan masih mempengaruhi praktek kehidupan jemaat Kristen Jawa pada waktu itu. ${ }^{34}$ Itu berarti bahwa dzikir telah menjadi sarana pujian kepada Allah dalam agama-agama orang Jawa; hanya yang khas bagi Toenggoel Woeloeng adalah tambahan yang menegaskan "Yesus Kristus Putra Allah dan Roh Allah".

\section{Injil Sebagai Ngelmu Kristen}

Toenggoel Woeloeng menjelajahi seluruh pulau Jawa dan dengan caranya sendiri memberitakan Injil. Selaku seorang guru Jawa yang sejati, disampaikannya berita Injil sebagai kebijaksanaan, ngelmu. Ia pernah menjelaskan kepada Janz bahwa pelajaran yang diberikannya sesudah ia menjadi seorang Kristen tidaklah jauh berbeda dengan apa yang diberikannya di lereng Gunung Kelud. ${ }^{35}$ Dasa Titah, Doa Bapa Kami dan Pengakuan Iman Rasuli difungsikan sebagai rumusan doa dan mantramantra (rapal), jika dihafal dan disyarati dengan laku-laku tertentu akan menghasilkan daya magis tersendiri. ${ }^{36}$ Karena Injil dianggap sebagai ngelmu Kristen, maka Toenggoel Woeloeng seringkali menyebarkan Injil dengan jalan "adu ngelmu". Ini adalah suatu teknik khas Jawa, yakni dengan perdebatan antara beberapa guru agama. Yang kalah akan tunduk kepada kiai yang menang dan menjadikannya sebagai gurunya karena ilmu dan kekuatannya lebih besar. ${ }^{37}$

Dalam pandangan Kiai Toenggoel Woeloeng, inti agama Kristen adalah ajaran baru bahwa ajaran lama diinkorporasi sehingga juga seorang seperti Muhammad mendapat tempat di dalamnya. Menurut Janz, mengenai kematian Yesus, gagasan-gagasan Toenggoel Woeloeng masih bersifat Islam. Sayang Janz tidak menjelaskan hal itu. ${ }^{38}$ Setelah beberapa tahun kemudian Janz melaporkan:

\footnotetext{
${ }^{33}$ Koentjaraningrat, Kebudayaan Jawa, (Jakarta: Balai Pustaka, 1994), 363

${ }^{34}$ Soetarman Soediman Patronadi, Komunitas Sadarch dan Akar Kontekstualnya..., 157-159

${ }^{35}$ A.G. Hoekema, Berpikir dalam Keseimbangan yang Dinamis....., 64-67

${ }^{36}$ J.D. Walterbeek, Babad Zending di Pulau Jawa....., 15

${ }^{37}$ C. Guillot, Kiai Sadrach: Riwayat Kristenisasi di Jawa....., 59-60

38 A.G. Hoekema, Berpikir dalam Keseimbangan yang Dinamis....., 68
} 
Bagi Tunggul Wulung, kisah-kisah dan cerita dalam Injil tidak punya hubungan sedikit pun dengan realitas, melainkan hanya ucapan-ucapan mistik yang harus dijelaskan lagi... Cerita kelahiran Yesus bukanlah peristiwa yang sudah terjadi tetapi sesuatu yang akan terjadi pada masa mendatang. Sementara itu, Yesus menjelma menjadi orang atau benda. Yudea, Yerusalem, Betlehem, bukanlah tempat-tempat yang benar-benar ada, tetapi kata-kata yang maknanya yang terselubung masih harus dicari. ${ }^{39}$

Kepribadiannya memang luar biasa. Bagi misionaris Belanda, dia jelas seorang guru ngelmu yang memperkaya pengetahuan yang dipunyainya sebelumnya dengan ajaran agama Kristen. Harus diakui bahwa pribadinya mengejutkan mereka yang menemuinya. Inilah pendapat dari beberapa misionaris:

Haezoo: "Ia memiliki pengetahuan yang luas tentang Islam Jawa dan dia pergunakan ungkapan-ungkapan Arab, yang menurut dia sesuai dengan pengajaran agama Kristen, baik makna maupun tujuannya."

Poensen (misionaris dari Kediri): "Dia memang sarat dengan 'ngelmu'. Saya yakin bahwa yang diajarkannya kepada muridmuridnya lebih banyak ngelmu yang berasal dari Hindu-Budha daripada Kristen."

Ganswijk: "Pengetahuannya tentang Injil sangat dangkal.",40

Jadi ajaran agama Kristen dari Kiai Toenggoel Woeloeng mempunyai corak khusus, yaitu merupakan bentuk sinkretisme antara ajaran agama Kristen dengan aliran Kebatinan Jawa dan agama Islam. Oleh sebab itu, maka Janz menolak membaptiskannya karena pengetahuan agama Kristen Toenggoel Woeloeng masih lemah.

Para pekabar Injil Belanda menolak pemberitaan Injil sebagai ngelmu berdasarkan pemahaman mereka akan ngelmu. Mereka merasa bahwa konsep ngelmu merupakan kesatuan yang tidak terpisahkan dengan Jawaisme, yaitu kombinasi antara agama asli dengan Hinduisme, Buddhisme dan Islam. Ngelmu dalam konteks ini mencakup kemampuan manusia mempergunakan kekuatan supernatural dalam dunia nyata kekuatan ilahi yang mempengaruhi kehidupan manusia melalui keberuntungan dan kemalangan - yang mengarahkannya pada masalah

\footnotetext{
${ }^{39}$ C. Guillot, Kiai Sadrach: Riwayat Kristenisasi di Jawa...., 45

${ }^{40}$ C. Guillot, Kiai Sadrach: Riwayat Kristenisasi di Jawa....., 45
} 
manusia semata-mata. ${ }^{41}$ Hortsman misalnya, sangat menentang pemakaian ngelmu karena ia mendapati bahwa di Pekalongan dan daerah-daerah sekitarnya, para penatua bertindak sebagai dhukun sunat dan guru ngelmu yang menyembuhkan orang sakit dengan mengucapkan rapal dan memuja dewa agar memperoleh hasil panen yang baik, kelahiran yang selamat dan tujuan-tujuan duniawi lainnya. ${ }^{42}$

Demikian juga Toenggoel Woeloeng memakai cara-cara seorang dukun dalam mengobati orang sakit dan menggunakan rumus-rumus Kristen seperti Doa Bapa Kami dan sebagainya dalam usaha pengobatan itu. Akkeren menyatakan bahwa otoritasnya ialah kharisma, yakni kesaktian yang ia peroleh kala ia menjadi seorang pertapa. Ia juga melakukan kunjungan manakala ada orang sakit, lalu ia akan menyembuhkannya dengan jalan menggosok, meludah atau meniup pada bagian tubuh yang sakit, atau juga ia akan berkomat-kamit terhadap sang penderita. ${ }^{43}$ Berdasarkan hal tersebut dapatlah dimaklumi penjelasan Drewes, yaitu bahwa Kiai Ibrahim adalah guru agama biasa dan juga dukun yang ternama di kalangan penduduk. Untuk itulah ia meneruskan parktekpraktek magis, seperti dukun lain, tetapi dengan istilah-istilah Kristen dalam doa-doanya. ${ }^{44}$

Hal di atas tentunya memperkuat pandangan para pekabar Injil yang berpendapat bahwa ngelmu hanya sekadar pengetahuan keagamaan yang spekulatif dan berbau takhayul yang ditampakkan oleh mistikisme, magis dan sinkretisme. Dengan pemahaman akan ngelmu yang seperti itu, keberatan mereka akan penggunaannya dalam pekabaran Injil dapat dimengerti.

\section{Kristologi Ratu Adil}

Seperti Coolen di Ngoro, peranan Toenggoel Woeloeng dalam desadesa Kristen yang didirikannya yaitu: pendiri, kepala desa, pengajar dan pengkhotbah Ratu Adil Isa Rohollah. ${ }^{45}$ Oleh karena itu, ajaran agama

${ }^{41}$ Soetarman Soediman Patronadi, Komunitas Sadarch dan Akar Kontekstualnya....., 228-229

${ }^{42}$ Surat Hortsman kepada J. Wilhelm, tertanggal Oktober 1891 (Arsip NGZV, Leusden). Dalam Soetarman Soediman Patronadi, Komunitas Sadarch dan Akar Kontekstualnya: Suatu Ekspresi Kekristenan Jawa pada Abad XIX, Widi Herijati Rahadi, terj., (Jakarta: BPK Gunung Mulia, 2001), 229

${ }^{43}$ Philip van Akkeren, Dewi Sri dan Kristus....., 210

${ }^{44}$ Drewes, G.W.J., Drie Javaansche Goeroe's Leiden, 1925. Dalam C. Guillot, Kiai Sadrach: Riwayat Kristenisasi di Jawa, Asvi Warman Adam, terj., (Jakarta: PT Grafiti Pers, 1985), 46

${ }^{45}$ Philip van Akkeren, Dewi Sri dan Kristus...... 
Kristen Toenggoel Woeloeng mempunyai corak khusus, yaitu merupakan bentuk sinkretisme antara ajaran agama Kristen dengan aliran Kebatinan Jawa dan Islam. Ia mengatakan bahwa pada suatu saat akan datang Ratu Adil ke dunia untuk membawa keadilan, kebahagiaan bagi umat manusia.

Setiap bangsa yang menjadi Kristen harus punya pemimpinnya sendiri yang dapat dilihat. Bahwa orang Jawa bergabung dengan penginjil Eropa adalah salah: mereka harus menjadi orang Kristen Jawa dan mencari Kristusnya "sendiri". Oleh sebab itu, para murid Toenggoel Woeloeng mengharapkan bahwa Ratu Adil akan datang di sekitar Bondo. Dalam ramalan mengenai Ratu Adil, menurut Harthroon dapat ditunjukkan empat kurun waktu yang dihubungkan dengan simbol empat warna vandel: putih, kuning, pelangi, dan warna daun-daun gugur (= Toenggoel Woeloeng, bendera biru-hitam). Vandel terakhir itu tergolong dalam kurun waktu yang membawa kebijaksanaan sejati, ngelmu sejati. $^{46}$

Dengan pemberitaan Kristus sebagai Ratu Adil, para pekabar Injil merasa inti terdalam Kristologi sedikit banyak terancam. Ratu Adil, yang disebut pula Erucakra atau Mahdi (Dia yang akan datang), dalam kepercayaan Jawa juga berfungsi sebagai guru moral. Ia sangat sering dikaitkan dengan tokoh mistis dan legendaris yang merupakan penjelmaan dewa, datang ke dunia sebagai manusia biasa selama rentang waktu tertentu untuk membawa ketertiban bagi dunia yang kacau. Bila misi ilahinya telah selesai ia akan kembali ke surga. Penentangan para pekabar Injil terletak pada sifat Ratu Adil dan misinya yang mereka pandang sangat berbeda dengan sifat dan misi Kristus. ${ }^{47}$

\section{Sifat Mistik Pengajaran Kiai Toenggoel Woeloeng}

Dari uraian sebelumnya kita ketahui bahwa Kiai Toenggoel Woeloeng bertapa di Gunung Kelud selama bertahun-tahun. Dengan bertapa ia berharap dapat memahami makna kehidupan dan memperoleh kebenaran sejati serta menyatukan diri dengan Tuhan. Hal ini menunjukkan sifat mistik dari Kiai Toenggoel Woeloeng. Ada banyak misionaris yang memiliki keraguan akan pengetahuan Toenggoel Woeloeng tentang ajaran agama Kristen. Alasan utama keraguan mereka berkaitan dengan cara Kiai Toenggoel Woeloeng merangkaikan gagasan-gagasan Kristen dengan konsep-konsep mistik dan apokaliptik Jawa. Hoekema menyatakan bahwa Kiai Toenggoel Woeloeng adalah seorang guru yang punya wewenang, yang memperkenalkan ajaran yang sebagian baru. Pengajarannya antara

\footnotetext{
${ }^{46}$ A.G. Hoekema, Berpikir dalam Keseimbangan yang Dinamis..., 65, 69

47 Soetarman Soediman Patronadi, Komunitas Sadarch dan Akar Kontekstualnya...,
} 227 
lain diungkapkan dengan rumusan doa dan mantra-mantra (rapal). Begitulah Dasa Titah, Doa Bapa Kami dan Pengakuan Iman Rasuli berfungsi baginya. ${ }^{48}$

Sebagaimana halnya Coolen, Kiai Toenggoel Woeloeng pun kurang terpelajar. Keduanya memiliki sikap "orang lapangan", berbeda dengan Tosari dan Sadrach yang lebih memiliki figur "intelektual" dengan membaca dan menafsirkan Kitab Suci. Pada Kiai Toenggoel Woeloeng, seperti juga pada Coolen, tampak aspek sinkretisme yang kentara. Ia pernah menjelaskan kepada Janz bahwa pelajaran yang diberikannya sesudah menjadi Kristen tidak begitu berbeda dengan apa yang dulu sebagai pertapa diberikannya di lereng Gunung Kelud. Dengan kata lain, bagi Toenggoel Woeloeng sebenarnya ajaran itu hanya berbeda kata-katanya tetapi isinya sama saja. Berkaitan dengan hal tersebut Herwanto menyatakan bahwa:

Ajaran agama Kristen dari Kiai Tunggul Wulung mempunyai corak khusus, yaitu merupakan bentuk sinkretisme antara ajaran agama Kristen dengan aliran kebatinan Jawa dan agama Islam. Ia mengatakan bahwa pada suatu saat akan datang Ratu Adil ke dunia untuk membawa keadilan, kebahagiaan bagi umat manusia. Doa Bapa Kami harus diucapkan sebagai rapal karena doa tersebut dapat menjauhkan manusia dari berbagai kesukaran hidup. ${ }^{49}$

Jadi, ajaran Kiai Toenggoel Woeloeng dapat dikatakan mempunyai kecenderungan pada Kebatinan dan mistik. Kebatinan merupakan paduan dari okultisme, metafisik, mistik dan doktrin-doktrin lainnya, suatu ramuan khas kebolehan orang Jawa untuk mengadakan sintesis.

Kita lihat pula bahwa dia menganggap Islam serupa dengan Kristen, "baik isi ajarannya maupun tujuan agama itu." Dia melangkah lebih jauh dalam hal keyakinan ini, karena ia melarang pengikutnya menjelekkan sedikit pun Nabi Muhammad, karena "Muhammad juga dihormati dalam Injil." Akhirnya, seperti Coolen, ia juga menggunakan konsep Ratu Adil, mesias Jawa, dalam mengajarkan agama Kristen. Selain itu, yang perlu menjadi sorotan dalam pengajaran agama Kristen yang dilakukan oleh Kiai Toenggoel Woeloeng adalah mengenai visi esoteris dari Kitab Suci. Janz melaporkan bahwa bagi Kiai Toenggoel Woeloeng, kisah-kisah dan cerita dalam Injil tidak punya hubungan sedikit pun dengan realitas, melainkan hanya ucapan-ucapan mistik yang harus dijelaskan lagi. Cerita kelahiran

48 A.G. Hoekema, Berpikir dalam Keseimbangan yang Dinamis: Sejarah Lahirnya Teologi Protestan Nasional di Indonesia (Sekitar 1860 - 1960), Amsy Susilaradeya, terj., (Jakarta: BPK Gunung Mulia, 1997), 66

${ }^{49}$ Lydia Herwanto, Pikiran Dan Aksi Kiai Sadrach: ....., 50 
Yesus bukanlah peristiwa yang sudah terjadi tetapi sesuatu yang akan terjadi pada masa mendatang. Sementara itu, Yesus menjelma menjadi orang atau benda. ${ }^{50}$

Berdasarkan hal-hal di atas, dapatlah dimaklumi bahwa sebenarnya Kiai Toenggoel Woeloeng adalah guru agama biasa dan juga dukun yang ternama di kalangan penduduk. Untuk itulah ia meneruskan praktek-praktek magis, seperti dukun lain, tetapi dengan istilah-istilah Kristen dalam doadoanya. Banyak misionaris yang berpendapat bahwa pengetahuannya tentang Injil sangat dangkal, bahkan dia sarat dengan 'ngelmu' sehingga diyakini bahwa yang diajarkannya kepada murid-muridnya lebih banyak ngelmu yang berasal dari Hindu-Budha daripada Kristen. Selain itu, ia memiliki pengetahuan yang luas tentang Islam Jawa dan dia pergunakan ungkapan-ungkapan Arab, yang menurut dia sesuai dengan pengajaran agama Kristen, baik makna maupun tujuannya.

\section{BAB II \\ KESATUAN ALLAH DAN MANUSIA DALAM PERSPEKTIF INJIL YOHANES 17:20-23}

Injil Yohanes adalah Injil Spiritual, bahkan ada yang menamakannya piagam persatuan Kristen sehingga kekristenan yang diajarkan oleh Rasul Yohanes tidak lain adalah semacam ajaran kekristenan mistik. Persatuan mistik juga merupakan salah satu di antara teologi Paulus dan bahkan inti dari agama yang diajarkan oleh sang rasul karena elemen-elemen esensial tentang persatuan mistik ditemukan dalam surat-surat kiriman Rasul Paulus. Oleh sebab itu, kedua rasul tersebut disinyalir oleh teolog-teolog tertentu telah mengajarkan doktrin persatuan mistik. ${ }^{51}$ Berdasarkan hal tersebut, maka penulis tertarik untuk menggunakan kebenaran firman Tuhan, yaitu Injil Yohanes 17:20-23, sebagai dasar untuk menyoroti mistik Toenggoel Woeloeng.

Ada beberapa kata dalam teks tersebut yang menarik untuk dianalisis. Pertama, adalah kata percaya yang dalam bahasa Yunani adalah pisteuo. Kata tersebut diikuti dengan kata eis, yang artinya kepercayaan, itu ditujukan kepada suatu oknum atau person. Selain itu, pada waktu kita percaya kepada seseorang, kita sepertinya masuk pada orang itu dan berserah sepenuhnya pada pribadi orang itu, dan kalau kita memperhatikan

\footnotetext{
${ }^{50}$ C. Guillot, Kiai Sadrach: Riwayat Kristenisasi di Jawa, ...., 45

${ }^{51}$ Hali Daniel Lie, Jurnal Teologi dan Pelayanan “Veritas”, (Malang: SAAT, 2001), 
konteksnya maka akan jelas bahwa person yang menjadi objek iman tersebut adalah Tuhan Yesus.

Dalam Injil Yohanes, iman menduduki tempat yang sangat mencolok, terlihat dari munculnya kata kerja pisteuo sampai 98 kali. $^{52}$ Tetapi yang perlu digarisbawahi adalah bahwa kata benda "iman" tidak muncul dalam Injil Yohanes, walaupun kata kerjanya "percaya" sering muncul. Agaknya kegemaran Yohanes akan kata kerja itu disebabkan oleh kebutuhan untuk menekankan tindakan percaya daripada isi kepercayaan itu sendiri, karena di seluruh kitab Injil ini iman dianggap sebagai soal hubungan, bukan soal pengakuan. ${ }^{53}$ Iman bukanlah suatu persetujuan yang kosong terhadap halhal tentang firman, tetapi suatu persetujuan untuk menerima Kristus, dimana kita mempercayakan diri pada-Nya dan mematuhi Dia sebagai Juru Selamat. ${ }^{54}$

Jadi, jelaslah bahwa iman (percaya) kepada Tuhan Yesus akan membawa orang untuk memiliki persekutuan atau menjadi satu denganNya. Dalam teks ini juga dinyatakan bahwa orang-orang bisa percaya kepada Yesus adalah melalui "pemberitaan" para murid. Kata "pemberitaan" dalam teks Yunani adalah lo,gou (noun genitive masculine singular from lo,goj).

Frasa dia. tou/ lo,gou auvtw/n mengindikasikan bahwa kesaksian para rasul tersebut adalah tentang Kristus, dan kesaksian tersebut menjadi sebuah pendahuluan yang penting bagi iman.

Selanjutnya adalah frasa "di dalam" dalam teks Yunani adalah evn. Wenham menjelaskan bahwa evn + datif berarti "di" atau "di dalam", karena datif juga dipakai untuk menyatakan tempat (lokatif). ${ }^{55}$ evn preposisi dengan dativ dapat diartikan di dalam, di atas, pada, dengan tempat atau hal apapun, dengan gagasan utama bersandar/meletakkan. Bila dibandingkan dengan eis, into or unto, dan ek, out of or from, maka en berada di antara keduanya; eis menyiratkan gerakan ke dalam, dan ek gerakan ke luar dari, sementara en, di (dalam), yang berarti tinggal pada tempatnya. ${ }^{56}$ Dalam TDNT dinyatakan bahwa evn tersebut adalah "the en of fellowship":

52 J.D. Douglas (ed), Ensiklopedi Alkitab Masa Kini, Jilid I (A-L), terj., (Jakarta: YKBK/OMF, 2002), 432

${ }^{53}$ Donald Guthrie, Teologi Perjanjian Baru 2: Misi Kristus, Roh Kudus, Kehidupan Kristen, Jan S. Aritonang, terj., (Jakarta: BPK Gunung Mulia, 1996), 222-223

${ }^{54}$ Thomas Manton, An Exposition of John 17, (Wilmington, Delaware: Sovereign Grace Publisher, 1972), 349

55 J.W. Wenham, Bahasa Yunani Koine....., 25

56 Spiros Zodhiates (ed), The Complete Word Study Dictionary: New Testament, (Chattanooga: AMG Publisher, 1993), 579 
In John and 1 John we have the en of religious fellowship, often with einai (Jn. 10:38; 1Jn. 2:5b, etc.) or ménein (Jn. 6:56; 1Jn. 2:6, etc.). Reciprocity is frequently stressed (Jn. 6:56; $1 \mathrm{Jn}$. 3:24, etc.). The Father is brought into the relationship, either with Jesus (Jn. $10: 38$ ) or with us (1Jn. 4:12-13, etc.). We thus have a triangle (Jn. $14: 20 ; 17: 21 ; 1 \mathrm{Jn} .2: 24)$. The formulas are neither ecstatic nor eschatological but mystical in a very broad sense with a strong personal and ethical reference (1Jn. 1:3); cf. construction with agáp $\bar{e}$ and lógos (Jn. 15:10; 1Jn. 2:14). There is no hint of the sacred marriage, nor are there any Hellenistic or Gnostic parallels. $^{57}$

Mereka yang "di dalam Kristus" maksudnya adalah orang Kristen. Secara khusus mereka yang dalam hubungan dengan Kristus, dalam iman Kristen. Kristus di dalam orang percaya dan sebaliknya, sebagai akibat dari iman dalam Dia. Berkenaan dengan bagaimana kesatuan itu bisa terjadi Bruce berpendapat bahwa:

That this vital unity through Christ with God is maintained and attested by indwelling Spirit is clear, even if this aspect of the Spirit's ministry is not spelled out expressly in these chapters as it is elsewhere in the NT (cf. I John 4:13, 'By this we know that we abide in him and he in us, because he has given us of his own Spirit'). ${ }^{58}$

Selanjutnya dinyatakan juga bahwa tujuan dari kesatuan tersebut adalah "supaya dunia percaya, bahwa Engkau-lah yang telah mengutus Aku". Kata "percaya" tersebut dalam teks Yunani adalah pisteu,sh| (verb subjunctive aorist active 3rd person singular from pisteu,w). Modus subjunktif dipakai untuk menyatakan sesuatu yang tak tentu. ${ }^{59}$ Lebih lanjut modus ini adalah modus yang menegaskan kemungkinan objektif. Modus ini menganggap bahwa tindakan bukanlah suatu fakta yang terjadi sekarang, tetapi kemungkinan atau berpotensi menjadi fakta, tergantung kepada situasi. Ini adalah modus probabilitas, yang dipergunakan dalam nasihat, peringatan, pertanyaan deliberatif (menimbang), larangan, dan kalimat kondisi. ${ }^{60}$ Mengenai kata "percaya" tersebut Thayer menyatakan "pisteu,w followed by o[ti with a sentence in which either the nature and

${ }^{57}$ Gerhard Kittel, Theological Dictionary of the New Testament: Abridged In One Volume, (Grand Rapids, Michigan: Wm.B. Eerdmans Publishing Company, 1986), 234

${ }^{58}$ F.F. Bruce, The Gospel of John ....., 336

${ }^{59}$ Ola Tulluan, Bahasa Yunani, (Batu: Literatur YPPII, 2007), 160

${ }^{60}$ William Douglas Chamberlain, An Exegetical Grammar of the Greek......, 82 
dignity of Christ or his blessings are set forth". ${ }^{61}$ Bila kita kaitkan dengan teks di bagian lain maka jelaslah bahwa tujuan atau konsekuensi dari kesatuan itu adalah bahwa dunia paling sedikit akan diyakinkan (bdk. 16:8) mengenai misi Yesus dan bahwa Ia adalah "Juruselamat dunia" (4:42).

Berdasarkan analisis eksegetis dari beberapa kata di atas jelaslah terdapat suatu hubungan mistis antara orang-orang percaya dan Kristus, atau orang-orang percaya dan Allah. Gagasan ini diungkapkan dengan frasa yang khas, yaitu "ada di dalam" Yesus. Hal ini seringkali disebut sebagai "mistisisme Yohanes" dan tidak ada definisi yang jelas. Ada saling tinggal dari orang-orang percaya di dalam Kristus dan Kristus di dalam orangorang percaya. Ini sejalan dengan Anak tinggal di dalam Bapa dan Bapa tinggal di dalam Anak (Yoh. 17:21, 23). Namun dalam kesatuan tersebut tidak ada penggabungan pribadi atau penghilangan identitas manusia. Tidak ada bukti bahwa mistisisme Yohanes menimbulkan kondisi ekstase atau trance. Sebaliknya, hal itu adalah mistisisme pribadi dan persekutuan etika yang meliputi kehendak ketimbang emosi. Jadi mistisisme ini dibarengi dengan tuntutan etis. Selain itu, kesatuan orang percaya dengan Kristus mencakup juga kesatuannya dengan orang lain, dan kesatuan tersebut mempunyai kepentingan dan tujuan bersama.

\section{BAB III SOROTAN YOHANES 17:20-23 TENTANG KESATUAN ALLAH DAN MANUSIA TERHADAP MISTIK TOENGGOEL WOELOENG}

\section{Memahami Mistik Jawa untuk Memahami Mistik Toenggoel Woeloeng}

Keyakinan orang Jawa yang beragama Agami Jawi terhadap Tuhan sangat mendalam dan hal itu dituangkan dalam suatu istilah Gusti Allah Ingkang Maha Kuwaos. Sumber yang paling utama bagi konsep mengenai Tuhan pada orang Agami Jawi adalah buku Nawaruci. Menurut konsepsi Agami Jawi Tuhan adalah keseluruhan dalam alam dunia ini, yang dilambangkan dengan wujud suatu makhluk dewa yang sangat kecil, sehingga setiap waktu dapat masuk ke dalam hati sanubari orang; tetapi Tuhan sekaligus juga besar dan luas seperti samudera, tidak berujung dan tidak berpangkal seperti angkasa, terdiri dari semua warna yang ada di dunia. Demikianlah pandangan orang Jawa yang sifatnya pantheistis, mengenal Tuhan. Koentjaraningrat sendiri menyatakan bahwa sebenarnya pandangan itu lebih tepat disebut pandangan theopanistis seperti yang

61 Joseph Henry Thayer, A Greek-English Lexicon of the New Testament, (Cambridge, Massachusetts: International Bible Translator Inc, 1889), 212 
disebut oleh ahli kesusastraan Hindhu, Vāth. Ia menyarankan agar perbedaan antar pandangan pantheistis dan theopanistis ialah bahwa yang pertama "semua adalah Tuhan", sedangkan yang kedua adalah "semuanya menjadi Tuhan". ${ }^{2}$ Berbeda dengan hal tersebut, ahli kesusastraan Jawa P.J. Zoetmulder memilih untuk menggunakan istilah pantheistis untuk keduaduanya. $^{63}$

Bagi orang-orang kejawen, "Tuhan" ada di hati, itulah "Tuhan" yang mereka rasakan; itulah Hidup dan bahwa mereka merupakan bagian daripada-Nya, atau, dalam istilah seorang ahli Kebatinan "Dalam setiap detak jantunglah saya merasakan 'Tuhan'. Ialah Hidup yang melingkungi saya dan saya menjadi bagian dari Hidup. Ia ada di dalam diri saya dan di luar saya. Itulah lahir, kawin, melahirkan kehidupan, kemudian mati. Semua yang ada itu Hidup, kesinambungan eksistensi, persinggahan kita di sini hanyalah berhenti sebentar di mana kita beristirahat untuk minum". Kehidupan mengalir dan kita mengalir dengannya, tugas kita adalah mencari kesinambungan dari aliran tersebut. Kita hidup dari asal ke tujuan. Kita datang, berhenti, dan menghilang. Kita tidak pergi ke mana-mana, melainkan memenuhi bagan Hidup. ${ }^{64}$ Secara modern prinsip Hidup ini bisa diringkas sebagai ke-Tuhanan Yang Maha Esa, yang dipahami sebagai prinsip ketuhanan yang mencakup segala-galanya atau "Tuhan". Kata seperti ke-Tuhan-an pada hakikatnya adalah samar dan penuh rahasia, yang lebih bereferensi pada ini kerahasiaan Hidup daripada Tuhan yang mewujud sebagai suatu pribadi.

Bagi Kebatinan "Tuhan" mengungkapkan diri secara langsung dalam hati setiap orang tanpa melalui perantara-perantara, baik itu berupa para nabi maupun berupa kitab-kitab suci. ${ }^{65}$ Bagi mereka "Tuhan" ada dalam hati manusia dan hidup manusia sendiri harus menjadi doa terus-menerus kepada Yang Maha Kuasa. Mereka tidak mengerti mengapa orang harus bersembahyang lima kali sehari, atau mengapa harus dalam gereja, mengapa doa mesti diteriakkan keras-keras dari pengeras-pengeras suara mesjid. "Tuhan" bukanlah hakim yang jauh dan tidak terdekati, sebaliknya "Tuhan" begitu dekat dengan manusia lebih dari apapun juga, karena pada dasarnya manusia adalah bagian dari "Hakikat Ilahi". ${ }^{66}$ Pernyataan Hadiwijono dan Geertz seperti yang dikutip oleh Subagya adalah demikian:

\footnotetext{
${ }^{62}$ Koentjaraningrat, Kebudayaan ....., 322-323

${ }^{63}$ P.J. Zoetmulder, Manunggaling Kawula Gusti: Pantheisme Dan Monisme dalam Sastra Suluk Jawa, (Jakarta: Gramedia Pustaka Utama, 1991), 12

${ }^{64}$ Niels Mulder, Pribadi dan Masyarakat Djawa, (Yogyakarta: Sinar Harapan, 1985), 22

${ }^{65}$ Niels Mulder, Kebatinan dan Hidup Sehari-hari Orang Jawa: kelangsungan dan perubahan kulturil, (Jakarta: Gramedia, 1983), 5

${ }^{66}$ Ibid., 11
} 
Ajaran Serad Wirid bersifat anthroposentris, sikap terhadap Tuhan adalah negatif; manifestasi dari nan mutlak adalah sebenarnya manifestasi manusia. Sedangkan Clifford Geertz menarik kesimpulan sama: kebenaran pasti asasi (pada mereka) selalu terletak dalam kesamaan: rasa=aku=Tuhan. Itulah dianggap cukup dibenarkan oleh pengalaman batin, yang membuktikan dirinya. ${ }^{67}$

Ke-Tuhan-an dapat dirasakan dalam batin seseorang, dan merupakan suatu pengalaman dan pertemuan pribadi dengan hakikat dan kebenaran. Ini bukan merupakan suatu konfrontasi dengan sesuatu yang berada di luar diri, tetapi penegasan bahwa seseorang berpartisipasi dalam kesatuan eksistensi. Dalam pandangan kejawen, praktek keagamaan formal harus dianggap sebagai suatu persiapan untuk bertemu dengan ketuhanan dalam diri, untuk menyadari bahwa ia pada hakikatnya adalah sebagian dari suatu susunan besar.

Geertz yang memiliki formula "rasa $=\mathrm{aku}=$ Tuhan" menyatakan bahwa "rasa" itu ada dalam perasaan murni manusia yang sekaligus kedirian individu (aku) itu. Rasa juga sebagai manifestasi Gusti Allah dalam individu itu. ${ }^{68}$ Zoetmulder menyatakan bahwa hal tersebut tidak berdiri sendiri tetapi ada presedennya dalam mistik Islam. Di sana pun kita berjumpa dengan bersemayam-Nya Tuhan di dalam hati manusia, atau lebih tepat, di bagian paling halus dalam hati manusia yang dinamakan sirr (rahasia). ${ }^{69}$ Hal yang sama juga nampak bila kita merujuk pada ajaran "Martabat Tujuh" dari R. Ng. Ranggawarsita, sebagaimana dinyatakan oleh simuh, bahwa rasa itu menjadi unsur yang terdalam dari tujuh martabat dan Gusti Allah berada dalam rasa itu. ${ }^{70}$

Menurut Zoetmulder, dewa (baca: Tuhan) yang bersemayam di dalam lubuk hati (baca: rasa) dengan sifat niskala atau immaterialnya itu dapat dimohon keluar menjadi bentuk yang terpersepsi (bentuk sakala, material) dengan cara bertapa atau yoga. ${ }^{71}$ Kediaman Allah di dalam manusia itu sedemikian rupa, sehingga kata-kata Tuhan Yesus yang mengenai Diri-Nya dapat diterapkan kepada "manusia yang sempurna", yaitu: "Barangsiapa telah melihat Aku, ia telah melihat Bapa" (Yoh. 14:9). Sebab di dalam ajaran Serad Wirid tentang "Allah di dalam Manusia" disebutkan bahwa rupa kita dikuasai oleh Zat yang indah, nama kita adalah sebutan Zat yang

\footnotetext{
${ }^{67}$ Rahmat Subagya, Kepercayaan dan Agama, (Yogyakarta: Kanisius, 1976), 53

68 Clifford Geertz, Abangan, Santri, Priyayi dalam Masyarakat Jawa, (Jakarta: Pustaka Jaya, 1983), 416

${ }^{69}$ P.J. Zoetmulder, Manunggaling Kawula Gusti..., 214

${ }^{70}$ Simuh, Mistik Dalam Islam Kejawen R.Ng. Ranggawarsita: Suatu Studi Terhadap Serat Wirid Hidayat Jati, (Jakarta: UI Press, 1998), 332

71 P.J. Zoetmulder, Kalangwan: Sastra Jawa Kuno Selayang Pandang, (Jakarta: Djambatan, 1994), 209
} 
kuasa, pekerjaan kita adalah karya Zat yang sempurna. Bahkan Zat Tuhan yang Maha Tinggi itu melihat hanya memakai mata kita, mendengar memakai telinga kita, bersabda memakai mulut kita, merasakan segala rasa memakai rasa kita, lahir batin Allah sudah berada di dalam hidup kita pribadi. Bahkan terdapat pernyataan yang paling radikal diungkapkan oleh Suluk Malang Sumirang, demikian: "Tiada Allah, sebab kamulah Allah itu, lahir-batin Allah adalah kamu, segala huruf menggantikan huruf alef, Allah adalah kamu". 72

Berdasarkan hal-hal tersebut di atas maka dapat disimpulkan bahwa sifat imanen Gusti itu ada di dalam diri manusia; yang mana dalam martabat tujuh manusia itu dikatakan sebagai sifat hayat Tuhan. Bila hal ini dikaitkan dengan pertapaan Toenggoel Woeloeng di Gunung Kelud maka dapat juga disimpulkan bahwa Toenggoel Woeloeng telah berusaha "memohon paksa" dewa yang setidaknya untuk mewujud menjadi dirinya sehingga ia mencapai "kesempurnaan". Hal-hal inilah yang mempengaruhi mistik Kristen Kejawen Toenggoel Woeloeng, yaitu bahwa ia adalah Kanjeng Rama Ana atau Kristus yang kelihatan. Menurut mistik Manunggaling Kawula-Gusti tersebut sebenarnya Tuhan ada di mana-mana dan juga di dalam diri pribadi manusia. Ajaran bahwa Tuhan terdapat di dalam segala dan bahwa segala ada terdapat di dalam Tuhan jelas berakar pada agama Hindhu sehingga tidaklah terlalu mengherankan jika di masa beralihnya agama Hindhu ke agama Islam tampil ke muka seorang Syekh Siti Jenar yang antara lain pernah berkata, "Saya ini Allah".

\section{Sorotan Yohanes 17:20-23}

\section{Terhadap Mistik Manunggaling Kawula-Gusti}

Dalam bagian ini penulis akan menyoroti tentang kesatuan Allah dan manusia dalam mistik Manunggaling Kawula-Gusti yang sangat berpengaruh terhadap mistik Kristen Kejawen Toenggoel Woeloeng, dan hal tersebut sangatlah bertentangan dengan pengajaran Alkitab.

1. Dalam mistik Jawa (Manunggaling Kawula-Gusti), ditegaskan bahwa satu-satunya sumber untuk pengakuan Tuhan adalah pengalaman batin manusia sendiri. Untuk menggantikan firman Tuhan diutamakan ilham dari dalam atau suara batin sendiri. Hal ini sangat berbeda dengan pengajaran dalam Yohanes 17:20-23 karena dalam bagian ini Tuhan Yesus berdoa bagi orang-orang yang akan percaya kepada-Nya melalui "kesaksian" para murid. Kesaksian tersebut termasuk juga tulisantulisan para rasul sebagaimana pemberitaan mereka. Hal ini dapat kita

${ }^{72}$ Harun Hadiwijono, Kebatinan Jawa dalam Abad 19, (Jakarta: BPK Gunung Mulia, 1985), 30-33 
hubungkan dengan tujuan Yohanes menulis Injil-nya yaitu bahwa "semua yang tercantum di sini telah dicatat, supaya kamu percaya, bahwa Yesus-lah Mesias, Anak Allah, dan supaya kamu oleh imanmu memperoleh hidup dalam nama-Nya". Hal tersebut mengindikasikan bahwa firman itu menjadi pendahuluan yang penting bagi iman, yang jika dihubungkan dengan pengajaran Alkitab di bagian lain akan jelas bahwa "iman timbul dari pendengaran, dan pendengaran oleh firman Kristus". Jadi orang dapat percaya/mengenal Allah dari firman.

Dari hal-hal di atas nampak bahwa yang menjadi dasar ide Yohanes tentang iman adalah pengertian kepercayaan yang sederhana dan menerima kebenaran saksi-saksi terhadap pribadi dan misi Yesus. Jika kita menghubungkannya dengan bagian lain dalam Injil Yohanes, maka akan jelas bahwa manusia dipanggil untuk mempercayai kesaksian Kitab Suci (Yoh. 2:22), Musa dan tulisan-tulisannya (Yoh. 5:46-47) dan di atas semua ini, mempercayai firman (Yoh. 2:22; 4:50; 5:47b) dan karya Yesus (Yoh. 10:38) yang pada gilirannya berarti percaya kepada Yesus sendiri (Yoh. 5:38, 46b; 6:30; 8:31, 45, 46; 10:37, 38a). Percaya kepada Yesus dan firman-Nya berarti percaya kepada Allah (Yoh. 5:24).

2. Dalam mistik Manunggaling Kawula-Gusti terdapat pemahaman bahwa untuk bersatu dengan Tuhan maka manusia harus memiliki pengetahuan tentang dirinya sendiri, yaitu pengetahuan "sangkan paraning urip" atau asal dan tujuan hidupnya. Oleh karena itu, banyak aliran Kebatinan meletakkan tujuan manusia dalam pemulangan jiwa kepada Tuhan, tetapi hasrat kembali kepada Tuhan itu dipahami secara gnostik. Tidak diperbedakan antara pribadi dan zat manusia. Zat manusia tidak diakui berkepribadian otonom. Manusia digambarkan sebagai emanasi (pantulan, sorot, pletikan, dll) dari Zat Abadi. Di sini manusia mengerjakan sendiri suatu pengalaman yang disebut rohani. Tidak dengan dasar iman, melainkan berdasarkan kepercayaan pada dirinya sendiri. Tidak pula dalam sikap menunggu turunnya anugerah, melainkan dalam usaha mencapainya oleh dayanya sendiri. Samadhi Kebatinan, katanya, menyebabkan otomatis rasa kesatuan dengan nilai mutlak. Jalan yang ditempuh oleh mawas diri, ingat, olah rasa, dan samadhi, dengan sendirinya berakhir pada suatu pandangan yang disebut rasa kesatuan dengan Zat Tertinggi. Rasa itu dibuat dengan sendiri dengan dupa, dzikir atau renungan. Mereka berdaya upaya untuk mecapai hal-hal tersebut dengan mengorbankan kenikmatan duniawi. Mereka menghaluskan martabat insani dan mengabaikan hiburan-hiburan kasar dari "hormat, nikmat, uang".

Hal di atas sangatlah berbeda dengan pengajaran Alkitab dalam Yohanes 17:20-23. Untuk manusia bisa bersekutu dengan Allah 
diperlukan iman. Sesuai dengan pengertian Yohanes, dalam hal ini kita harus memandang iman sebagai suatu penyerahan diri sepenuh hati yang oleh karenanya orang beriman menjadi satu dengan Kristus dan berada dalam Kristus. Yohanes banyak berbicara tentang "tinggal di dalam" Kristus; ke dalam keadaan semacam itulah iman membawa kita masuk. Tercatat bahwa iman kadang-kadang dimengerti dalam arti "menerima amanat", yakni kepercayaan bahwa sesuatu yang dikatakan adalah benar. Sesudah kebangkitan Kristus murid-murid-Nya pun "percayalah akan Kitab Suci dan akan perkataan yang telah diucapkan Yesus" (Yoh. 2:22). Tetapi iman lebih sering diarahkan kepada Yesus sendiri dan mencakup unsur mempercayakan diri kepada-Nya (Yoh. 17:20). Beberapa kali iman didorong oleh pekerjaan-pekerjaan Yesus. Jika kita melihat dalam keseluruhan kitab Injil Yohanes maka akan terlihat pentingnya iman tersebut.

Selain itu, usaha untuk bersatu dengan Allah dengan mengandalkan kekuatan sendiri dalam mistik Jawa sangatlah bertentangan dengan pengajaran Alkitab. Hal tersebut karena iman yang dimaksudkan adalah lebih ditekankan sebagai respon manusia terhadap tawaran kasih Allah dan anugerah keselamatan-Nya. Jadi tidak terlihat kontradiksi bahwa iman adalah keputusan bebas dari kehendak manusia dan sekaligus adalah pemberian anugerah Allah. Ini menjelaskan bahwa keputusan iman itu bukan hasil usaha manusia seperti usaha-usaha orang Yahudi terhadap Taurat, tetapi semata-mata jawaban yang cocok yang dimungkinkan oleh anugerah Allah kepada wahyu yang diberikan oleh Yesus. Hal anugerah ini juga nampak dari inisitaif dan tindakan Yesus sendiri dalam memberikan "kemuliaan" yang telah diberikan Bapa-Nya supaya terjadi kesatuan.

3. Mistik Manunggaling Kawula-Gusti bukanlah sembarang pertemuan dengan Tuhan dalam suara hati nurani, melainkan kesatuan dengan Tuhan ditujukan untuk "Pamoring kawula-Gusti". Dalam teori mistik Jawa, tujuan itu dilukiskan sebagai kesadaran diri manusia tenggelam dalam ketuhanan dan kehilangan kepribadiannya sendiri. Kesatuan ini merupakan peleburan antara hamba dan Tuhan, di mana tiada lagi perbedaan antara yang menyembah dan yang disembah.

Dalam Yohanes 17:20-23 juga membahas mengenai kesatuan antara manusia dengan Allah, yaitu ada saling tinggal dari orang-orang percaya di dalam Kristus dan Kristus di dalam orang-orang percaya. Namun yang membedakan adalah bahwa dalam kesatuan tersebut tidak ada penggabungan pribadi atau penghilangan identitas manusia. Tidak ada bukti bahwa kesatuan dalam Injil Yohanes menimbulkan kondisi ekstase atau trance. Sebaliknya hal itu adalah mistisisme pribadi dan persekutuan etika yang meliputi kehendak ketimbang emosi. Persatuan 
orang percaya dengan Kristus juga bukan persatuan hakikat yang membuat kepribadian manusia hancur atau terserap sama sekali ke dalam Kristus atau Allah.

4. Mistik Manunggaling Kawula-Gusti memiliki tujuan bahwa manusia akan menjadi "manusia sempurna" di mana Allah dijadikan nyata di dalam manusia, atau Allah direalisasikan di dalam manusia. Sebagai tokoh di mana Allah menjadi nyata, "manusia sempurna" memiliki juga segala sifat Allah. Ia adalah Khalik serta penyelamat dunia. Ia adalah yang Mahakuasa, yang Mahatinggi serta yang Mahasuci. Segala sesuatu mungkin baginya, sebab segala sesuatu ditaklukkan kepadanya. Ia tidak terikat kepada hukum apapun, sebab ia sendiri adalah hukum bagi segala sesuatu. Selain itu, "manusia sempurna" juga dapat menggulung keadaannya sendiri untuk dikembalikan kepada asalnya, yaitu pada saat ia meninggalkan dunia ini. Ia adalah "Juruselamat"nya sendiri, sekalipun ia bukan Juruselamat dunia.

Hal tersebut bertentangan dengan pengajaran dalam Yohanes 17:20-23, karena dalam teks ini terlihat bahwa persatuan orang percaya dengan Kristus jauh melebihi persatuan karena mempunyai kepentingan dan tujuan bersama. Kesatuan orang percaya dengan Kristus mencakup juga kesatuannya dengan orang lain. Tujuan dari semua itu adalah "supaya dunia percaya, bahwa Engkau-lah yang telah mengutus Aku". Jadi tujuannya adalah supaya dunia diyakinkan (bdk. 16:8) mengenai misi Yesus dan bahwa Ia adalah "Juruselamat dunia" (4:42). Jadi tujuannya bukan menjadikan orang percaya sebagai "Juruselamat". Jika kita memperluas hal ini dalam tulisan Yohanes, maka akan semakin jelas perbedaannya, yaitu bahwa kesatuan tersebut dibarengi dengan tuntutan etis. Ini terutama terlihat dalam 1 Yohanes. Orang yang tinggal di dalam Kristus wajib hidup sama seperti Kristus telah hidup (1 Yoh. 2:6). Ia harus menuruti segala perintah-Nya (1 Yoh. 3:24). Gagasan bahwa Allah diam di dalam kita sangat erat dihubungkan dengan dampak etisnya, sampai-sampai Yohanes berkata, "Barangsiapa tetap berada di dalam kasih, ia tetap berada di dalam Allah dan Allah di dalam dia" (1 Yoh. 4:16).

Berdasarkan sorotan-sorotan di atas maka jelaslah bahwa konsep Toenggoel Woeloeng mengenai dirinya sebagai Kanjeng Rama Ana atau Kristus yang kelihatan adalah tidak alkitabiah sehingga tidak dapat dibenarkan karena hal itu merupakan sinkretisme. Hal ini dilatar belakangi bahwa ia adalah seorang Jawa yang tidak mau meninggalkan kebiasaan nenek moyangnya yang telah berurat akar dalam masyarakatnya. Ia beranggapan bahwa pelajaran yang diberikannya sesudah ia menjadi seorang Kristen tidaklah jauh berbeda dengan apa yang diberikannya di lereng Gunung Kelud. 
Dengan menyebut dirinya sebagai Kanjeng Rama Ana sebenarnya dapatlah disimpulkan bahwa dia sedang memposisikan dirinya sebagai "manusia sempurna" dalam pengertian mistik Jawa. Itu berarti bahwa dia adalah representasi dari Allah Bapa, atau dengan kata lain ia sedang menyejajarkan dirinya dengan Kristus. Sehingga tidaklah mengherankan kalau dia mengajarkan bahwa setiap bangsa yang menjadi Kristen harus punya pemimpinnya sendiri yang dapat dilihat. Bahwa orang Jawa bergabung dengan penginjil Eropa adalah salah: mereka harus menjadi orang Kristen Jawa dan mencari Kristus-nya "sendiri". Oleh sebab itu, para murid Toenggoel Woeloeng mengharapkan bahwa Ratu Adil akan datang di sekitar Bondo. Pengajarannya lebih mudah diterima oleh orang Jawa, sehingga pengikutnya banyak, bahkan ia dipuja-puja oleh pengikutnya sebagai kiai dan dianggap sakti serta punya kekuatan magis karena ia punya kesaktian dari pertapaanya di Gunung Kelud.

\section{SIMPULAN}

Bila kita tinjau mistik Toenggoel Woeloeng dalam terang firman Tuhan, secara khusus dari Yoh. 17:20-23, maka jelaslah bahwa konsep Toenggoel Woeloeng mengenai dirinya sebagai Kanjeng Rama Ana atau Kristus yang kelihatan adalah tidak alkitabiah sehingga tidak dapat dibenarkan karena hal itu merupakan sinkretisme. Hal ini dilatarbelakangi bahwa ia adalah seorang Jawa yang tidak mau meninggalkan kebiasaan nenek moyangnya yang telah berurat akar dalam masyarakatnya. Ia beranggapan bahwa pelajaran yang diberikannya sesudah ia menjadi seorang Kristen tidaklah jauh berbeda dengan apa yang diberikannya di lereng Gunung Kelud.

Dengan menyebut dirinya sebagai Kanjeng Rama Ana sebenarnya dapatlah disimpulkan bahwa dia sedang memposisikan dirinya sebagai "manusia sempurna" dalam pengertian mistik Jawa. Itu berarti bahwa dia adalah representasi dari Allah Bapa, atau dengan kata lain ia sedang menyejajarkan dirinya dengan Kristus. Sehingga tidaklah mengherankan kalau dia mengajarkan bahwa setiap bangsa yang menjadi Kristen harus punya pemimpinnya sendiri yang dapat dilihat. Bahwa orang Jawa bergabung dengan penginjil Eropa adalah salah: mereka harus menjadi orang Kristen Jawa dan mencari Kristus-nya "sendiri". Oleh sebab itu, para murid Toenggoel Woeloeng mengharapkan bahwa Ratu Adil akan datang di sekitar Bondo. Pengajarannya lebih mudah diterima oleh orang Jawa, sehingga pengikutnya banyak, bahkan ia dipuja-puja oleh pengikutnya sebagai kiai dan dianggap sakti serta punya kekuatan magis karena ia punya kesaktian dari pertapaanya di Gunung Kelud. 


\section{DAFTAR PUSTAKA}

den End,Th. van

1980 Ragi Carita 1: Sejarah Gereja Di Indonesia th. 1500 - th. 1860. Jakarta: BPK Gunung Mulia

2000 Ragi Carita 2: Sejarah Gereja Di Indonesia 1860-an sekarang. Jakarta: BPK Gunung Mulia

Douglas, J.D. (ed)

1996 Ensiklopedi Alkitab Masa Kini, Jilid I (A-L), terj. Jakarta:

YKBK/OMF

G.W.J., Drewes

1985 Drie Javaansche Goeroe's Leiden, 1925. Dalam C. Guillot,

Kiai Sadrach: Riwayat Kristenisasi di Jawa, Asvi Warman Adam, terj. Jakarta: PT Grafiti Pers

Geertz, Clifford

1983 Abangan, Santri, Priyayi Dalam Masyarakat Jawa. Jakarta: Pustaka Jaya

Guillot, C.

1985 Kiai Sadrach: Riwayat Kristenisasi di Jawa, Asvi Warman Adam, terj. (Jakarta: PT Grafiti Pers

Guthrie, Donald

1996 Teologi Perjanjian Baru 2: Misi Kristus, Roh Kudus, Kehidupan Kristen, Jan S. Aritonang, terj. Jakarta: BPK Gunung Mulia

Hadiwijono, Harun

1985 Kebatinan Jawa dalam Abad 19. Jakarta: BPK Gunung Mulia

Herwanto, Lydia

2002 Pikiran dan Aksi Kiai Sadrach: Gerakan Jemaat Kristen Jawa Merdeka. Jogjakarta: MATABANGSA 
Hoekema, A.G.

1997 Berpikir dalam Keseimbangan yang Dinamis: Sejarah Lahirnya Teologi Protestan Nasional di Indonesia (Sekitar 1860-1960), Amsy Susilaradeya, terj. Jakarta: BPK Gunung Mulia

Kittel, Gerhard

1986 Theological Dictionary of the New Testament: Abridged In One Volume. Grand Rapids, Michigan: Wm.B. Eerdmans Publishing Company

Koentjaraningrat

1994 Kebudayaan Jawa. Jakarta: Balai Pustaka

Kruger, Th. Muller

1966 Sedjarah Geredja di Indonesia, Tjetakan kedua. Djakarta:

Badan Penerbit Kristen

Manton, Thomas

1972 An Exposition of John 17. Wilmington, Delaware: Sovereign Grace Publisher

Mulder, Niels

1983 Kebatinan dan Hidup Sehari-hari Orang Jawa: kelangsungan dan perubahan Kulturil. Jakarta: Gramedia

1985 Pribadi dan Masyarakat Djawa. Yogyakarta: Sinar Harapan

Simuh

1998 Mistik dalam Islam Kejawen R.Ng. Ranggawarsita: Suatu Studi terhadap Serat Wirid Hidayat Jati. Jakarta: UI Press

Soediman Patronadi, Soetarman

2001 Komunitas Sadarch dan Akar Kontekstualnya: Suatu Ekspresi Kekristenan Jawa pada Abad XIX, Widi Herijati Rahadi, terj. Jakarta: BPK Gunung Mulia

Subagya, Rahmat

1976 Kepercayaan Dan Agama. Yogyakarta: Kanisius. 
Thayer, Joseph Henry

1889 A Greek-English Lexicon of the New Testament. Cambridge, Massachusetts: International Bible Translator Inc.

Tulluan, Ola

2007 Bahasa Yunan. Batu: Literatur YPPII

van Akkeren, Philip

1981 Philip "Darmogandul Suluk Karangan Ngabdullah Tunggul

Wulung Hubungannya Dengan Pekabaran Injil Di Jawa Timur", Dalam Mengenang 50 tahun Majelis Agung Gereja Kristen Jawi Wetan, Suharo dan Sardjonan, red. Pp. 138-144. Malang: Majelis Agung GKJW

1995 Dewi Sri dan Kristus: Sebuah Kajian tentang Gereja Pribumi di Jawa Timur. B.A. Abednego, terj. Jakarta: BPK Gunung Mulia

Walterbeek, J.D.

1995 Babad Zending di Pulau Jawa. Yogyakarta: Taman Pustaka Kristen

Warsito

1973 Di Sekitar Kebatinan. Jakarta: Bulan Bintang

Zodhiates Spiros (ed)

1993 The Complete Word Study Dictionary: New Testament. Chattanooga: AMG Publisher

Zoetmulder, P.J.

1991 Manunggaling Kawula Gusti: Pantheisme dan Monisme dalam Sastra Suluk Jawa. Jakarta: Gramedia Pustaka Utama

1994 Kalangwan: Sastra Jawa Kuno Selayang Pandang. Jakarta: Djambatan 